\title{
Consultar, Diagnosticar e Tratar
}

\author{
Georg Tuppy
}

Araçatuba, SP

$\mathrm{O}$ ato médico essencial consiste na consulta, onde se estabelece contato com o paciente para realizar o diagnóstico e orientar o tratamento. Nesta relação única e particular, entram em jogo inúmeros aspectos importantes, freqüentemente esquecidos, que dizem respeito ao médico e ao paciente e que devem sempre ser considerados com atenção.

Temos nós, médicos, nos preocupado adequadamente com o ser humano que nos procura? Será que, a cada nova consulta, nos lembramos de entender àquele que está à nossa frente, quais são suas angústias, necessidades e expectativas em relação ao contato que se estabelece? Será que consideramos a estrutura sócio-econômica-cultural e religiosa na qual se baseiam suas queixas; compreendemos sua individualidade e temos consciência das repercussões que nossas atitudes e palavras terão sobre ele e seus familiares? Valorizar e respeitar cada um destes aspectos parece-me fundamental para que se estabeleçam bases éticas sólidas entre os atores deste cenário. $\mathrm{O}$ paciente nunca deve ser reduzido à sua doença ou tratado como um objeto.

Para que isto ocorra é necessário, em primeiro lugar, que haja um profundo respeito e compaixão por aquele que nos procura. Temos que dar a ele o direito de expressar suas queixas, inicialmente sem nossa interferência, por um período de tempo maior que o usualmente empregado. Vejo, com freqüência, relatos de doentes que foram consultados em tempos exíguos, em que não lhes foi permitido expressar verbalmente suas queixas e sequer foram tocados pelo médico! A que tipo de diagnóstico pode-se chegar agindo desta maneira? Como é reconhecido um profissional que tem esta atitude? Não seria a desatenção para com o ser humano a causa do crescente desrespeito social vivido pela classe médica e da freqüente procura das "formas alternativas" da medicina pelos doentes?

Afinal o que deseja o paciente? Estará ele somente in-

Cardioclínica Araçatuba S/C Ltda

Correspondência: Georg Tupy - Cardioclínica Araçatuba - Rua Tiradentes, 1301 16015-020 - Araçatuba, SP - E-mail: gtuppy@uol.com.br

Recebido para publicação em 9/9/01

Aceito em 17/10/01 teressado em prolongar sua vida a qualquer custo ou diminuir seu sofrimento? Será que ele prefere um diagnóstico frio e rápido de seu mal, embasado em porcentagens de cura e sobrevivência, após exames caros e demorados; ou então a atenção carinhosa para com suas queixas, a compreensão de sua doença e de seus reflexos sobre sua pessoa e entorno social? Esta segunda abordagem, apoiada em um conhecimento científico sólido e constantemente renovado, ao reforçar os processos internos de cura usados exaustivamente pelos xamãs e ignorados por nós, trará um resultado mais benéfico levando o doente a ter uma melhor qualidade de vida.

Após estabelecido o diagnóstico, que tipo de preocupação temos em relação ao tratamento proposto? Observo, com freqüência em minha prática, pacientes que desconhecem que moléstia têm, suas causas e prognóstico, nome, dose e tempo de uso dos medicamentos. A explicação cuidadosa sobre a doença e tipo de terapêutica a ser usado, com detalhamento de seus possíveis efeitos positivos e negativos, com a preocupação dos custos emocionais e financeiros envolvidos e, principalmente, permitindo que o doente escolha aquilo que ele considera melhor para si, parece-me ser a conduta mais correta.

Devo salientar aqui que a melhora de nossa relação com os pacientes trará como conseqüência um maior respeito pelo nosso trabalho e pessoa, pois vale lembrar que somos tratados da maneira que tratamos os outros. O que nos adianta reclamar da desconsideração para com nossa profissão, por parte da sociedade, se não damos às pessoas o respeito que merecem? A resposta mais freqüente a esta assertiva é de que somos mal remunerados. Mas pergunto, que culpa tem aquele indivíduo fragilizado por sua doença e que nos procura nesta situação? Não será uma atitude pouco digna fazer dele uma vítima de nossas angústias e frustrações?

Com certeza muitos de nós professamos algum dos mais diferentes credos religiosos. Todos eles têm em sua base filosófica o amor e respeito ao próximo. Será que transferimos para nossas atitudes diárias aquilo que às vezes pregamos com tanta convicção?

Estamos também preocupados com o grau de violên- 
cia que encontramos em nossa sociedade. Não será uma forma séria de violência o não reconhecimento em cada paciente de um ser humano inteiro, frágil e carente, e às vezes usar desta condição para explorá-lo das mais diferentes maneiras?

Os aspectos acima tratados com certeza não esgotam um assunto tão complexo, mas devem servir de base para reflexão sobre as atitudes que tomamos em nossa prática diária e orientar mudanças que, além de levarem a um bem estar interior, geram um exemplo que ao se espalhar serve como nossa contribuição para uma sociedade mais digna e justa.

\section{Agradecimento}

Este artigo é dedicado ao Prof. Nain Sauaia, um verdadeiro mestre que plantou, em suas aulas de propedêutica, a semente, nunca esquecida, de um profundo respeito para com o paciente.

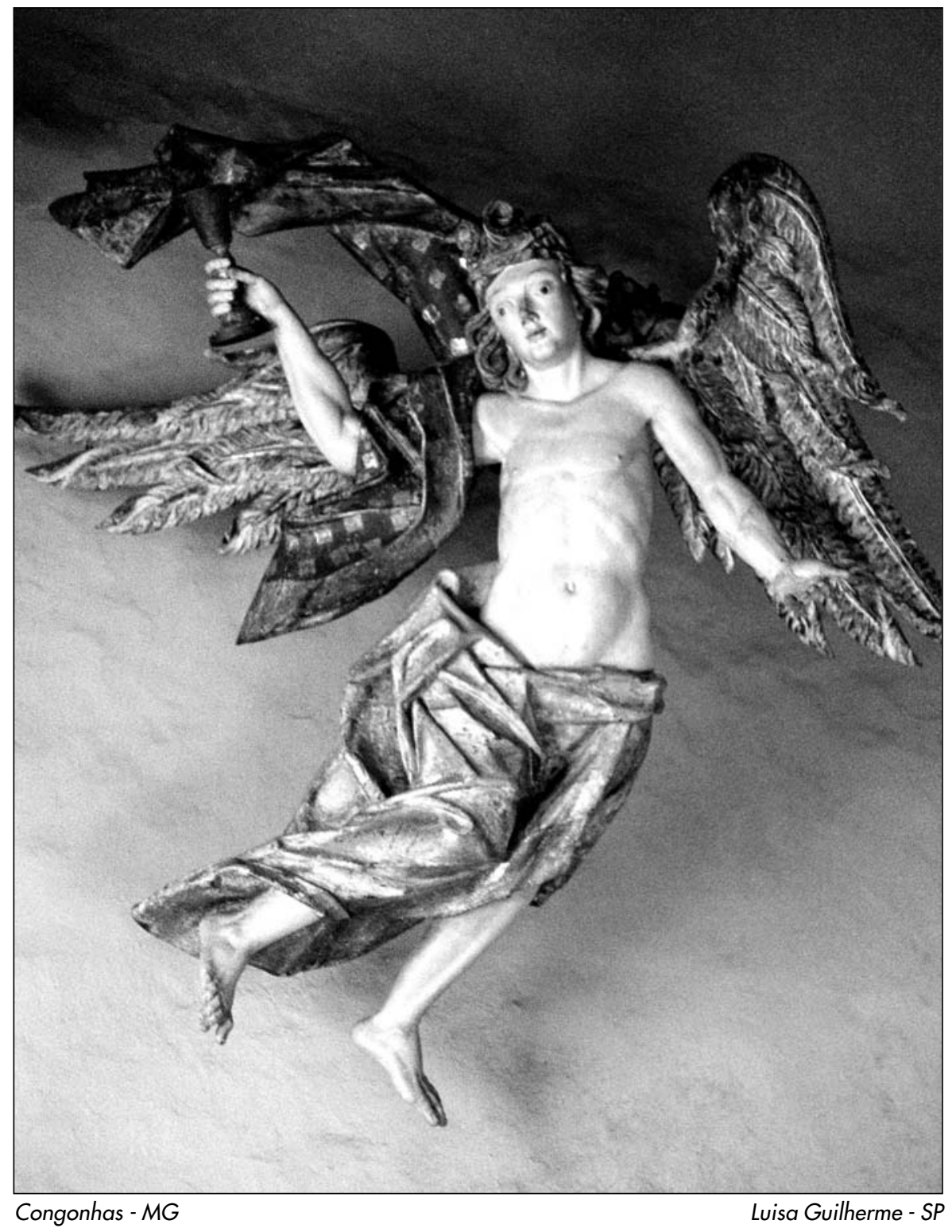

Editor da Seção de Fotografias Artísticas: Cícero Piva de Albuquerque

Correspondência: InCor - Av. Dr. Enéas C. Aguiar, 44 - 05403-000 - São Paulo, SP - E-mail: delcicero@incor. usp.br 